Espacio y Desarrollo No 27, 2015, pp. 103-118 (ISSN 1016-9148)
http://dx.doi.org/10.18800/espacioydesarrollo.201501.005

\title{
THE TRANSFORMATION OF PUBLIC ACTION - A NEW SPATIAL PLANNING PARADIGM IN PERU?
}

\author{
Ann-Kathrin Bersch \\ Sciences Po Paris, Francia \\ annkathrin.bersch@sciencespo.fr
}

\begin{abstract}
It appears that the situation of spatial planning policies in Peru is complicated. Several attempts to simplify legislations have failed. However, a coherent policy framework is necessary in order to efficiently implement a comprehensive spatial planning strategy. Therefore this paper considers the question of spatial planning through an analysis of public policy, in order to understand who has the power to make changes to create a common vision of spatial planning in Peru.

It analyzes which were the obstacles of change so far to illustrate how change did not happen (or happened only in a limited way). The first part sheds light on the conflicts between different levels of government. The second, analyzes how to conflicts of interest between actors within the government impede the elaboration of a coherent legislative framework. The last part discusses the possibility of a paradigm shift in Peruvian spatial planning policy and possible alternatives to the current model.
\end{abstract}

Key words: Spatial planning, Peru, public policy, transformation of public action.

La transformación de la acción pública - un nuevo paradigma de ordenamiento territorial en el Perú?

\section{RESUMEN}

La situación del ordenamiento territorial en Perú parece muy complicada. Varios intentos para simplificar la legislación han fallado. Sin embargo, un marco normativo coherente es indispensable para implementar una estrategia integral de ordenamiento territorial. Por lo tanto, ese artículo considera la cuestión del ordenamiento territorial a través un análisis de política pública, para entender quién tiene el poder de hacer cambios para crear una visión común de ordenamiento territorial en el Perú.

El artículo analiza cuáles son los obstáculos de ese cambio por ahora para ilustrar porque el cambio no ocurrió (u ocurrió solamente de manera limitada). La primera parte pone de relieve los conflictos entre diferentes niveles de gobierno. La segunda, analiza como los conflictos de intereses de los actores a dentro del gobierno impiden la elaboración de un marco normativo 
coherente. La última parte trata de la posibilidad de un cambio de paradigma en las políticas peruanas de ordenamiento territorial y de posibles alternativas al modelo actual.

Palabras clave: ordenamiento territorial, Perú, política pública, transformación de la acción pública.

\section{INTRODUCTION}

In 2013, for the first time in the history of the country, all actors concerned by spatial planning policies came together to elaborate a common vision for a new spatial planning policy in Peru. In this «National Agreement» - «Acuerdo Nacional», representatives of every level of government, political parties, civil society organizations and technical experts agreed to incite a «strategic, integrated, efficient and effective process of spatial planning and management, that ensures human development in the whole national territory, in an environment of peace» (Acuerdo Nacional, 2013). This agreement states clearly that all actors involved are interested in finding common ground on the issue of spatial planning.

Spatial planning is defined by the French geographer Roger Brunet as «voluntary and reflexive action of an entity over her territory, be it on a local, regional or national level» (Brunet, 1999, p. 27). In a broader sense, following the European Charter of Spatial Planning, it is the projection of public policies in space (Orea, 2002, p. 29), it "gives geographical expression to the economic, social, cultural and ecological policies of society» ${ }^{1}$ (European Union, 1983, p. 13). It is a "policy developed as an interdisciplinary and comprehensive approach directed towards a balanced regional development and the physical organization of space according to an overall strategy» (European Union, 1983, p. 13).

This overall strategy is not yet established in Peru. As spatial planning is a transversal subject that depends on very different actors in different sectors and levels of government, it is important to analyze who has the power to make changes in order to create a common vision of spatial planning in Peru. So far, several legislations exist in Peru, concerning spatial planning. They cover different levels of government (Ley Orgánica de Municipalidades [Ley 27972, 2003], Ley Orgánica de los Gobiernos Regionales [Ley 27867, 2003]), and different entities within the government (Lineamientos de Política para el Ordenamiento [Ministerio del Ambiente del Perú, 2013], Ley de Demarcación y Organización Territorial [Ley 27795, 2002]). Some of the legislations

\footnotetext{
1 http://www.coe.int/t/dgap/localdemocracy/cemat/VersionCharte/Charte_bil.pdf
} 
are even contradictory, i.e. the aforementioned law declaring national interest of the demarcation of national limits, ignoring local identities and contradicting the law on decentralization (Ley Orgánica de Bases de la Descentralización [Ley 27783, 2002]), which defines regions as spaces that should be «historically, economically, administratively, environmentally and culturally integrated» territorial units, organized by regional governments (Art. 28, Ley 27783, 2002).

It appears that the situation of spatial planning policies in Peru is complicated. Several attempts to simplify legislations have failed. The following paper analyzes which were the obstacles of change, and illustrates how change did not happen (or happened only in a limited way), through conflicts of interest between actors that are integrated in the state apparatus.

First, the absence of change due to conflict between different levels of government will be analyzed, following Pierre Mullers analysis on the French public policy model (Muller, 1992, p. 275), which, because of the strong centralization of the Peruvian state, can be in some ways compared to the Peruvian case. The second part will focus on conflicts between different interest groups within the government, based upon William Genieys' and Patrick Hassenteufels analysis of «programmatic actors» - «acteurs programmatiques» (Genieys \& Hassenteufel, 2012, p. 95). It will especially take into account the influence of the Ministry of Housing and Construction and the Ministry of the Environment that compete to promote their vision of spatial planning. Lastly, the possible existance of a process of social learning and of a $3^{\text {rd }}$ order change will be considered, following Peter Halls analysis of policy change (Hall, 1993, p. 278), in order to evaluate whether the construction of a global and integrated vision of spatial planning, within a binding legal framework is conceivable.

\section{Conflict Between Levels of Government}

Peru is a strongly centralized country, and in this sense, similar to France. The Constitution states that the principles of the Peruvian state are to be a democratic, unitary, independent, sovereign, and social state. Important to note is article 43 of the Constitution: «The state is one and indivisible. His government is unitary, representative and decentralized.» (Constitución Política del Perú, 1993). However, in spite of efforts of decentralization, Peru remains a very centralized state. The national level retains a great deal of power and an actual decentralization has not been achieved yet (Cabrera Echegaray, 2014).

At the same time, Peru is a very heterogeneous country, geographically, socially and economically, making an integrated and global vision that much more important and more difficult at the same time. It is characterized by economic and political centralism, leading to high levels of inequality and social exclusion as well as a strong 
concentration of national wealth and economic activities in the capital Lima (Glave, 2012). The capital concentrates one third of the population, as well as a large part of the political elite of the country. Being a large port, it is the center of Peruvian exportations (Villegas Samanez, 2014). Economically, the country is structured through a neoliberal model, based on the extraction and exportation of natural resources; the dominant sectors are mining, fishing and forestation. This, of course, is a significant difference to the French case, making the country vulnerable to outside market pressures and explains the power exerted onto the local governments from the national level: operations that are considered of «national interest» and «important for the development of the country as a whole» prevail often over restrictions established by local spatial planning regulations (Villegas Samanez, 2014).

The strong role of the state has implications on how change can happen. Pierre Muller (1992) states three elements of the French model of public policy, which influence change in public policy and which are applicable to the Peruvian case:

Definition of the political agenda by the state (p. 276): As stated above the politicaladministrative elite (in Lima) controls the political agenda for the most part. The lack of strong civil society organizations outside the capital limit social debate and create a «central environment of decision-making» («milieu décisionnel central») (p. 277), in which local considerations are not taken into account. In the case of spatial planning policies a clear repartition of competences and responsibilities is important, as well as mechanisms of communication to overcome conflicts of interest. This means, in more detail:

Specific representation of interest: In the case of France interests are represented through a model of «sectorial corporatism» (p. 276). For each sector, there is one powerful actor representing the state (p. 279). In Peru there is a rather strong influence of representatives of main economic sectors: mining, fishing and forestation, and ministries responsible for the extraction of resources have an important say. National economic development strategies dominate the national agenda (Cabrera Echegaray, 2014), which often leads to conflict with local and regional governments. At the same time, there is a gap between perception and reality of the economy by the society: Most Peruvians see their country mainly as agricultural; it forms part of the identity of many, as it constitutes the possibility of self-sufficiency in case of need (Villegas Samanez, 2014). Consequently, similar to the French case described by Pierre Muller, farmers constitute an influential social group, with an influence larger than their economic weight (Muller, 1992, p. 279).

Privileged place of the state in implementation of local public policies (Muller, 1992, p. 276): As already described above, due to the weight of the extraction of resources in the Peruvian economic development national politics prevail often over local and regional spatial planning initiatives. For instance, Art. 53 of the «Ley Orgánica de Gobiernos Regionales» (Ley 27867, 2003) defines functions of regional governments 
in terms of spatial planning, among others the formulation of regional plans, in accordance with local plans (Azpur, 2011, p. 10). Furthermore, Art. 79 of the "Ley Organica de Municipalidades» (Ley 27972, 2003) - defines spatial planning as an exclusively local competence, without stating to what exactly should be the reference for those plans (Azpur, 2011, p. 10). However, none of those laws establishes a mechanism of communication between levels of government (Azpur, 2011, p. 10) or ensures the implementation of local policies in case of conflict with national policies. This is one of the main reasons why it is so difficult to establish a global vision for spatial planning, and what is more, it underlines the necessity of communication mechanisms, which ensures that this vision can be put into practice, without one level of government dominating the others. Nevertheless, it is important to keep in mind that the process of decentralization is still in its beginnings in Peru, unlike in France. There is not enough pressure from local governments to question hierarchy, due to the lack of means and competences in Peruvian municipal and regional governments, unlike in France, where local politicians have influence, especially through the Senate (Muller, 1992, p. 287). Furthermore Peru is not part of a supranational organization with a similar integration as the European Union to question state authority from above (Muller, 1992). The "Comunidad Andina» (Andean Community) has no power to impose binding legislations onto national governments; it is rather a platform for coordination of policies between its member states. What is quite obvious is the influence of large supranational institutions like the World Bank in Peruvian politics or other outside actors, like the German cooperation agency (Gesellschaft für Internationale Zusammenarbeit - GIZ) which helped to build up the Ministry of Environment ${ }^{3}$. However, these institutions only reinforce the national governments power, as the national level justifies actions as prescribed by those institutions by stating that they are basically not having a choice and are obliged to follow their advice.

If the national level is as predominant in Peru as we have seen above - why has the central government not developed a national vision, clearly stating the predominance of the national level and its competence in spatial planning? Spatial planning does not only concern different levels of governments, it also implies the coordination of different sectors, as the organization of space has an impact on almost every aspect of social, economic and cultural life. Therefore, it is important to analyze how the Peruvian state is organized in terms of spatial planning. In the following part the different entities of government responsible for spatial planning are presented, as well as their interactions and how they compete in order to impose their vision of spatial planning onto a global vision for Peru.

\footnotetext{
2 Founded as Andean Pact in 1969, current member states: Bolivia, Colombia, Ecuador, Peru.

3 Source: https://www.giz.de/en/worldwide/13376.html - last accessed: 09/05/15
} 


\section{Conflict Between Different Entities of the Government}

In order to understand why there hasn't been an integrated vision of spatial planning, it is important to understand which entities of the government are responsible to create legislation on spatial planning. The national government is not a unitary actor, with one opinion, but a space where different actors negotiate to impose their perspectives.

Therefore it is important to apprehend the state as an assembly of interest groups, that each constitute a "programmatic actor» («acteurs programmatiques» [Genieys \& Hassenteufel, 2012, p. 95]). Programmatic actors are characterized by the sharing of a program of change (containing common objectives, a shared analysis of issues and the situation, collective arguments and reasoning to legitimize their action as well as a common advocacy of concrete measures and instruments [Genieys \& Hassenteufel, 2012, p. 95]). Furthermore they have to dispose of sufficient resources to orient and define the content of public action (positional resources in order to take decisions, expertise, legitimacy, relational resources as well as timely resources (Genieys \& Hassenteufel, 2012, p. 95). The existence of those actors is a precondition for change. The reinforcement of the position of power of one of those actors allows them to promote change; competing programmatic actors are involved in power struggles (Genieys \& Hassenteufel, 2012, p. 96).

The analysis of programmatic actors can reveal who can promote change (be "porteur du changement» [Genieys \& Hassenteufel, 2012, p. 92]) - in Peru, three entities push forward a spatial planning policy, with more or less force. In 2001, the presidency of the council of ministers (PCM) created an inter-ministerial commission for spatial planning, which defined the functions of every ministry concerning spatial planning. In this process, two branches developed between the Ministry of Housing and the CONAM (Villegas Samanez, 2014). The Consejo Nacional del Ambiente (National Environment Council), was created in early 1990s, when the issue of sustainable development and protection of the environment first arose, (in the context of the Rio Summit in 1992) (Novoa Goicochea, 2008, p. 124). Spatial planning was seen mainly as an instrument for environmental policy, not as a policy for development (Novoa Goicochea, 2008, p. 125). In 2008, the Ministry of Environment was created (MINAM), and it defined spatial planning as one of its main functions and disposes of a general direction of spatial planning.

Currently, those two ministries, the Ministry of Housing and the Ministry of Environment, can be considered as main programmatic actors in the elaboration of a new spatial planning policy, following the evaluation grid of Genieys and Hassenteufel. They each share a program of change and want to take the lead in the establishment of a national spatial planning policy. Furthermore, the CEPLAN (Centro Nacional de Planeamiento Estratégico), the National Center of Strategic Planning that was 
created in 2005, is supposed to be the leading entity in spatial planning. However, it has neither the competence nor the power to establish and impose binding rules. Its responsibility is restricted to strategic planning, without the integrated, more global approach that is needed for spatial planning in order to involve all the necessary actors (Villegas Samanez, 2014). Finally, as it has no particular focus, that would incite the center to share a program of change, it cannot be considered a programmatic actor (the following part also contains a more detailed analysis on this issue).

To begin with, the Ministry of Housing: It has a more market-oriented logic, prioritizes urban development as a crucial factor for national growth, and aims to integrate cities in their surrounding system through urban zoning policies (Cabrera Echegaray, 2014). Their objective is to foster urban development and integrate cities and markets within a larger system with their surroundings. They analyze issues from an economic perspective and set priority on how to encourage development, based on arguments of economic growth, considering urban centers as "engines of growth" (Cabrera Echegaray, 2014), as the basis of all the other activities that are organized in space. Urban centers are central markets, production areas, centers of consumption, and innovation. Therefore agriculture and other activities are supposed to adapt around those centers. The Ministry focuses through their instrument of urban zoning on how to integrate those surrounding areas in the development of the centers, by determining land use in and around urban areas. To be able to promote change, programmatic actors have to dispose of sufficient resources (be it positional resources in order to take decisions, expertise, legitimacy, relational resources or timely resources) (Genieys \& Hassenteufel, 2012, p. 95). As part of the executive, they dispose of a general direction on spatial planning, composed by experts on the subject. This, as well as the fact that the ministry has existed since 1969 gives it the necessary legitimacy. They have had the opportunity to accumulate expertise and tie important relations within the state apparatus, which is an important condition for power and influence.

Second, the Ministry of Environment: It has a strong priority on the protection of the environment. Its objective is to push forward a stronger notion of environmental protection to protect vulnerable areas effectively from overexploitation due to economic activities, especially in the mining and forestation industries. This protection should be insured through a national spatial planning policy. The ministry analyzes issues from an environmental perspective, with arguments of sustainability. As concrete measures and instruments the ministry disposes of guidelines («Lineamientos de política para el Ordenamiento Territorial»), defining spatial planning as a "policy, political and technical process of consensual decision-making with social, political, economic and technical actors in order to ensure an organized occupation and an sustainable use of the territory» (Ministerio del Ambiente del Perú, 2013). Their main instrument is «ecological and economic zoning» - «Zonificacion ecológica económica», ZEE, which 
benefits from a large appropriation by the population (Villegas Samanez, 2014). It defines potentials of different zones in an area. The zoning is elaborated by working with regional governments, setting a basis for regional and local spatial plans, it benefits of a "social legitimacy", and is often used in order to fight against abuses of the mining or the forestation industries (Villegas Samanez, 2014). However this zoning is neither compulsory nor binding law - it is rather a recommendation of land use. They dispose of sufficient resources, just as the Ministry of Housing, because as part of the executive they have decisional resources, their general direction on spatial planning guarantees expertise as well as a certain social legitimacy through the zoning policy. However the ministry exists only since 2008 and still struggles to impose its policies. It has legitimacy in environmental issues, but is not considered competent in economic issues, as the ministry lacks focus on development and investment of the areas for which spatial plans are elaborated. Even though their focus on protection and preserving of nature is very important in Peru, generally the economic argument prevails.

The aforementioned CEPLAN cannot be considered a programmatic actor. Its objective is to elaborate, coordinate, follow and evaluate government strategies (Art. 4, Ley del Sistema Nacional de Planeamiento Estratégico (D.L. 1088, 2008)) ${ }^{4}$. Additionally, it should define a common vision of the future, with strategic objectives and plans for «the country's harmonic and sustainable development as well as the reinforcement of democratic government» (Art. 1, D.L. N 1088, 2008). The CEPLAN analyzes issues from an inter-ministerial perspective; they depend on consensus between ministries and have no power to impose anything or reinforce any strategies legally. Their strategies are rather a recommendation for different ministries, to make an effort to coordinate their policies, if the ministries agree. Their argument is the advocacy for a more coordinated effort. As a concrete measure, the CEPLAN published the "Plan Bicentenario", a document to promote an integrated vision of development for Peru. It is based on the values of the Universal Declaration of Human Rights, and constitutes of a diagnostic of all the aspects of life in Peru, as well as Peru's place within globalization. It proposes a prospective analysis and sets objectives for future development. However, political consensus is necessary to reach those goals, and the CEPLAN is an institution that is only capable to propose such strategies, but is dependent on the different government entities to implement them. They do not have the resources to take decisions, are lacking expertise and legitimacy, as they are a very young entity. Representative for this lack of resources is the formulation in their "Plan Bicentenario: "If we are capable to regroup enough political will in order to reach the proposed goals and consequently become a more egalitarian society and more

\footnotetext{
http://www.ceplan.gob.pe/ceplan/legal/ley-sistema-nacional

5 http://www.ceplan.gob.pe/plan-bicentenario
} 
responsible citizens [...] we are on a good path to be a first world country until the middle of next century» (CEPLAN, 2013, p. 4). For the above-mentioned reasons, the CEPLAN cannot be considered as a programmatic actor, and is too weak in order to be able to promote change (be "porteur du changement» (Genieys \& Hassenteufel, 2012, p. 95).

Bearing in mind the framework of analysis on programmatic actors, put forward by William Genieys and Patrick Hassenteufel, change can be explained in terms of interactions between actors (Genieys \& Hassenteufel, 2012, p. 111). The authors distinguish six different types of interactions, and their ability to promote change:

(1) One group of programmatic actors is imposing itself; in consequence change happens according to their program. (2) A group of programmatic actors fails to impose itself, because of the number of veto actors and their resources; consequence: absence of change. (3) Several groups of programmatic actors are competing; one of them imposes itself and change happens according to the program of the imposing actor. (4) Several groups of programmatic actors are competing and neutralizing themselves or negotiating, resulting in an absence of change or only limited change. (5) Several groups of programmatic actors agree thanks to one or several intermediate actors, leading to limited change. (6) Compromise between one or several programmatic actors and one or several veto actors that play a role as intermediate actors, result in limited change (Genieys \& Hassenteufel, 2012, p. 110).

As a consequence of the foregoing analysis, in the case of spatial planning policy in Peru, scenario $\mathrm{n}^{\circ} 4$ can be considered appropriate: programmatic actors affront, but neutralize each other. The two ministries oppose each other, with different visions, each wanting to impose their perspective. Asked about the possibility to reach consensus in order to reconcile those approaches, a member of the general direction of spatial planning, from the Ministry of Housing, Eusebio Cabrera Echegaray states that it is "a concept that is not yet on the agenda, but that at some point it will have to become a topic on the agenda» (Cabrera Echegaray, 2014).

So far, there have been several attempts to create a new spatial planning law in Peru, but each lacking an integrated and global vision, allowing the actors to reach consensus: in 2008 under a different government, four propositions of law were introduced in Congress, however none of them was discussed because of different opinions whose proposal should be discussed first. In 2014, two different projects failed, one proposing the Ministry of Environment as leading entity, the other one the CEPLAN. A member of the Ministry of Environment states: «It's a game of political interests» and nobody wants to take a decision because they don't want to get into conflict with the other entities (Villegas Samanez, 2014). The Ministry of Environment is more active in the matter of spatial planning - but if the new spatial planning policy should unite all the actors involved from the state and the civil society, a leading entity that has already 
a clear focus on environmental protection will have difficulties to reach consensus (Villegas Samanez, 2014), therefore "dialogue is blocked» (Villegas Samanez, 2014).

The framework of analysis brought forward by Genieys and Hassenteufel tries to find an endogenous explication for change. It is focused on interacting actors (Genieys $\&$ Hassenteufel, 2012, p. 110). However it is important to note that there are very important exogenous factors and the articulation of both elements is very important. The context depends on these actors, as it is "partially constructed and promoted by public policy actors, that try to impose their representations faced with constraints» (p. 111).

The fact that Peru is an extreme diverse country can certainly be considered as one of the main limitations to elaborate an integrated vision of spatial planning: its complex territory is composed of numerous physical barriers that hinder coordination and articulation within the state and create mental barriers, between populations with completely different realities. Even if a national spatial planning policy would be approved tomorrow - those issues remain, habits and attitudes have to change as well, not only policies. As a «best case scenario» for at least limited change, following Genieys' and Hassenteufels framework number five would be imaginable: «several groups of programmatic actors agree thanks to one or several intermediate actors. It is possible to imagine the CEPLAN as an intermediate actor capable to negotiate between opposing actors» (Genieys \& Hassenteufel, 2012, p. 110). Jesús Villegas Samanez, representative of the Ministry of Environment, feels that some things are changing. In his opinion, there is now a new generation that knows more about its own country and that is travelling outside of Lima in order to get to know the different realities in their country. Before that, habitants of Lima, especially the political and administrative elites identified more with what happened in Europe than what happened in the Amazon region - it is Peru's main challenge to confront those problems, to surpass cultural barriers and surpass the economic model of primary exportation, where Lima is the one and only center, where all the resources are commercialized (Villegas Samanez, 2014). Then a dialogue between levels of government would be possible, because at the moment, the discourse of regional governments is rather «you don't know my reality, you have to live here to know it» (Villegas Samanez, 2014), which is destructive for an open dialogue.

\section{Limited Change - A Possibility of Social Learning?}

For an effective change to happen there is a need for a more thorough change in spatial planning policy in Peru. Peter Hall considers three different degrees in the process of policy changes: $1^{\text {st }}$ order change (where only the settings of instruments change, while overall goals remain the same), $2^{\text {nd }}$ order change where the basic techniques change due to dissatisfying past experiences), and finally a $3^{\text {rd }}$ order change (representing a radical 
shift with simultaneous changes in all three components) (Hall, 1993, p. 278). Those changes in policy can be considered social learning, if there has been a «deliberate attempt to adjust the goals or techniques of policy in response to past experience and new information» (Hall, 1993, p. 278).

After the foregoing analysis, it became apparent that there has been a $2^{\text {nd }}$ order change in Peruvian spatial planning policies. New instruments were introduced and improved through the lessons learned by past experiences. However in order to resolve the contradictions between different levels of government and opposing programmatic actors, it would be necessary to create a shared framework, a common ground on which all actors agree on. This common ground can be described as a policy paradigm; «The deliberation of public policy takes place within a realm of discourse; [...] policies are made within some system of ideas and standards which is comprehensible and plausible to the actors involved $»^{6}$ (Anderson, cited in Hall, 1993, p. 279). "Each paradigm contains its own account of how the world facing policymakers operates and each account is different, it is often impossible for the advocates of different paradigms to agree on a common body of data against which a technical judgment in favor of one paradigm over another might be made» (Hall, 1993, p. 280). Here we can observe the importance of ideas to policy making, as «those ideas specify goals of the policy and the kinds of instruments used to attain them, but also the very nature of the problems they are meant to be addressing" (Hall, 1993, p. 279). Those ideas constitute the paradigm, the prism through which policymakers see, for instance spatial planning and their role in it (Hall, 1993, p. 279).

A first step to establish such a paradigm has been the declaration that all the actors involved in spatial planning see the necessity to act in a consensual manner, as an integrated effort (Acuerdo Nacional, 2013). However, neither the goals of the policy nor what kind of instruments should be used precisely have been defined; therefore this cannot be considered as a policy paradigm.

Peter Hall's analysis has several implications: A change of paradigm is more sociological than scientific; the choice between paradigms is made rarely on scientific grounds alone. Such a change entails a set of judgments, which is very political, as the outcome will depend not only on arguments of competing fractions, but also on other factors like their positional advantages within a broader institutional framework; the resources they can mobilize in conflict and exogenous factors affecting the power of one set of actors (Hall, 1993, p. 280). Therefore, issues of authority are likely to be central to the process: faced with conflicting opinions of experts, policy makers have to decide who can be seen as authoritative? The movement from one paradigm to another is often a shift of authority.

\footnotetext{
6 Charles Anderson, «The Logic of Public Problems: Evaluation in Comparative Policy Research,» in Douglas Ashford (Ed.), Comparing Public Policies (Beverly Hills: Sage, 1978, p. 23).
} 
In this case study, two different paradigms can be observed, competing with each other for prevalence: one promoted by the Ministry of Housing, the other one by the Ministry of Environment. Each tried to put forward different instruments which constitutes a $2^{\text {nd }}$ order change, but there hasn't been a general shift in policy towards an integrated vision, which would constitute a paradigm change in the sense of Peter Hall's analysis (Hall, 1993, p. 279). We can see how the idea that each actor has of spatial planning, shapes the way they establish goals and the instruments needed in order to achieve those goals. The Ministry of Housing, focusing on urban development, is trying to promote investment in urban areas, through their policy of urban zoning; determining land uses in order to help cities be integrated into the market system (Cabrera Echegaray, 2014). At the same time the Ministry of Environment defends the vision that spatial planning is above all necessary for environmental protection. Their instrument of ecological economical zoning wants to limit economic activities in certain areas, in order to protect the eco-system (Ministerio del Ambiente del Perú, 2013). The main issue hindering change in Peru is the fact that those competing paradigms can be found within the same government, unlike the case put forward by Peter Hall, where a new macroeconomic policy paradigm was established through a change of government (Hall, 1993, p. 276). In Peru there is not only the dispute within the government on how spatial planning should be approached, but also within different levels of the government. While the national government is not willing to give up its prevalence in questions of land use, regional and local governments defend the opinion that they know best what is appropriate for their territory and claim that their spatial planning regulations should be binding law for all levels of government.

As stated above, the decision whether one paradigm is able to impose itself over another, is rarely made on scientific grounds alone; it is rather a sociological process, where the positioning of each actor within the institutional framework is very important (Hall, 1993, p. 280). In Peru, the actors that would have the most legitimacy through their experience in spatial planning (the ministries of Housing and of the Environment), are not necessarily capable to establish a common vision, because of their specific focus on one part of spatial planning (development vs. protection of the environment). The actor who would be capable of assembling different actors and levels of government under a common vision, the CEPLAN (National Center of Strategic Planning) is lacking expertise and power within the institutions of the Peruvian state as well as its own vision of how spatial planning should be implemented. However, this rather weak position could be transformed into an opportunity. Their relatively neutral position could be used as a basis of consensus between the competing actors. Therefore it would be necessary to revisit its position and competences within the institutional framework, once a global vision of spatial planning established. With a national spatial planning law established, regulating the relations between the different levels of government, 
the CEPLAN would need the authority over other entities of the government in order to be able to impose this law, through binding regulations. This would probably also implicate a move of the different general directorates on spatial planning of the two ministries in question towards the CEPLAN in order to ensure its expertise.

The lack of a global vision on spatial planning leads to insecurities on the side of international and national investors, while the lack of environmental protection threatens the bio-diversity, especially in the Amazon basin. Neither of those approaches alone can lead to a sustainable development. A paradigm change would be needed in order to conciliate those two approaches and create an integrated vision that involves all the actors.

One possible paradigm change could imply a shift away from the market-oriented logic, which is centralizing the majority of economic activities in the capital, and preventing other areas from developing. This would also imply a shift away from pressures of international companies under which the national government stands in order to integrate and respect local and regional agendas in the planning policies, without prevalence of the national level. At the same time, this would entail a shift towards sustainable development policies and environmental protection, which would enable the Ministry of Environment to emit binding rules in order to prevent abuse of natural resources and contamination of the environment, as a leading entity for spatial planning. This vision appears to be difficult to implement, as there are many powerful actors set against it, within the government and outside the government, especially economic actors. Furthermore, the practical implementation of this vision will be very difficult, as well as the control of the land use regulations are complicated in such a complex territory, which would call for strong local entities, capable to impose themselves.

As an alternative one could imagine to push through the Ministry of Housing's vision, to promote urban development and integration of cities and markets in order to promote national economic development, despite of the local conditions and without explicit consideration of the environment. In the perspective of the fact that Peru is still a developing country and has been struggling with weakening economic growth in the last ten years ${ }^{7}$, economic growth has to be a priority in order to secure jobs and economic development.

In view of with the necessity to establish a national vision of spatial planning, while having to struggle between competing entities within the government and between different levels of government, an open dialogue between all of them seems to be the only way to possibly reach consensus. At the moment, as mentioned before, it seems that there has not been a major shift in the policies of one of the competing actors that would imply a paradigm change. Peter Hall considers an instrumental change as

\footnotetext{
7 Source: http://liportal.giz.de/peru/wirtschaft-entwicklung/ - last accessed: 09/05/15.
} 
change of second order, as only the techniques change, while goals remain the same (Hall, 1993, p. 280). However it is possible to view an instrument as more complex than a mere technical instrument.

Following the analysis of Pierre Lascoumes and Patrick Le Galès, an instrument is associated with the agents that use it, that make it evolve and select the specialists to put it into practice (Lascoumes \& Le Galès, 2004, p. 14). In their opinion, an instrument can be considered an institution, because they determine partly how actors behave and transmit representations of issues (p. 16). Instrumentation can be a way to orient relations between political society and the civil society (p. 21). This way an instrument can be more revealing of change, than the classification of Peter Hall might suggest.

In this case each actor is implementing its instrument in order to promote its vision of spatial planning. They can gain visibility and legitimacy through the appropriation of population, which can reinforce their power in the negotiation on what vision of spatial planning will be implemented and who will be the leading entity in the process. However as there are two opposing forces working against each other and neutralizing each other - there is a significant blockage, which seems difficult to overcome within the existent constellation. It remains to be seen whether one of the actors will finally be able to impose its perspective, or whether a third party actor will come into play in order to negotiate a consensus between both. If a new policy paradigm would be agreed upon, this could be considered a process of social learning, as it would be a result of past lessons, combined with new information (Hall, 1993, p. 278) on the economic situation of the country, making a coherent spatial planning policy all the more necessary.

\section{Conclusion}

In the previous analysis, it became apparent what hinders a change in spatial planning policy in Peru. There is not only a blockage between the levels of government, but also a conflict within different actors of the government. The above-mentioned frameworks of analysis of public policy can explain part of this dilemma; however none of them delivers a complete explanation, let alone a solution. First of all, Pierre Muller's analysis (1992) is based upon the French model of public policy, which is only transposable in a limited way to the Peruvian case. Second, the analysis of Genieys and Hassenteufel permits to analyze the conflict of different programmatic actors wanting to impose their program of change. The fact that the context is not directly taken into account by this analysis is an important issue, however this also makes this framework very transposable to cases beyond France or Western Europe, as the specific context can be integrated throughout the case study. Lastly, Peter Hall's framework to identify different degrees of change is appropriate to understand how a policy paradigm is composed 
and what it takes to change it. However it underestimates the power of instruments beyond the fact that they are purely technical devices, without a political agenda and that they are therefore unable to promote a significant shift of policy, in contrast to the analysis of Pierre Lascoumes and Patrick le Galès.

As became apparent in the foregoing analysis, the perspective on a significant change in spatial planning policy in Peru remains uncertain. As stated in the introductory definitions, spatial planning is the geographical expression of policies (European Union, 1983, S. 13), given the complicated context in Peru, a thorough analysis of the blockage points is indispensable in order to better understand the situation and make change possible in the future.

\section{BibLIOGRAPHY}

Acuerdo Nacional (2013). Politica del Estado sobre ordenamiento y gestión territorial. Lima: Acuerdo Nacional.

Azpur, J. (2011). Análisis de la legislación sobre planificación territorial en el Perú. Lima: Grupo Propuesta Ciudadana.

Brunet, R. (1999). Les mots de la Géographie. Montpellier/Paris: RECLUS/la documentation francaise.

Cabrera Echegaray, E. (2014, May 2). La perspectiva del Ministerio de Vivienda sobre el ordenamiento territorial. (A.-K. Bersch, Interviewer)

CEPLAN (2013). Plan Bicentenario. Perú. Retrieved from http://www.ceplan.gob.pe/ plan-bicentenario

Constitución Política del Perú (1993).

D.L. Nº 1088 (2008). Ley del Sistema Nacional de Planeamiento Estratégico. Perú. Von http:// www.ceplan.gob.pe/ceplan/legal/ley-sistema-nacional abgerufen

European Union (1983). European regional/spatial planning Charter. Von http://www. coe.int/t/dgap/localdemocracy/cemat/VersionCharte/Charte_bil.pdf abgerufen

Genieys, W. \& Hassenteufel, P. (2012). Qui gouverne les politiques publiques? Par-delà la sociologie des élites. Gouvernement et action publique, 2012(2), 89-115. http://dx.doi. org/10.3917/gap.122.0089

Glave, M. (2012). Ordenamiento territorial y desarrollo en el Perú: Notas conceptuales y balance de logros y limitaciones. In M. Glave, Desarrollo rural y recursos naturales (pp. 123-165). Lima: GRADE.

Hall, P. (1993). Policy Paradigm, Social Learning and the State. Comparative Politics, 25(3), 275-296. http://dx.doi.org/10.2307/422246

Lascoumes, P. \& Le Galès, P. (2004). L’action publique saisie par ses instruments. In P. Lascoumes, \& P. Le Galès, Gouverner par les instruments (pp. 11-44). Paris: Presses de Sciences Po. 
Ley 27783. (2002). Ley Orgánica de Bases de la Descentralización.

Ley 27795. (2002). Ley de Demarcación y Organización Territorial.

Ley 27867. (2003). Ley Orgánica de Gobiernos Regionales.

Ley 27972. (2003). Ley Orgánica de Municipalidades.

Ministerio del Ambiente del Perú (2013). Lineamientos para la formulación de proyectos de inversión pública en materia de ordenamiento territorial. Lima: Ministerio del Ambiente.

Muller, P. (1992). Entre le local et l'Europe: la crise du modèle français de politiques publiques. Revue Française de Science Politique, 42(2), 275-297. http://dx.doi. org/10.3406/rfsp.1992.404297

Novoa Goicochea, Z. (2008). El ordenamiento del territorio en el Perú. Lima: Sociedad Geográfica de Lima.

Orea, D. G. (2002). Ordenación territorial. Madrid: Ediciones Mundi-Prensa.

Villegas Samanez, J. (2014, June 14). La perspectiva del Ministerio del Ambiente sobre el ordenamiento territorial (A.-K. Bersch, Interviewer).

Fecha de envío: 14 octubre, 2015

Fecha de aceptación: 18 diciembre, 2015 